\title{
The physiotherapeutic context of loss of dominant arm function due to occupational accidents
}

\author{
Anna Kostiukow' ${ }^{1}$ Elżbieta Kaluga', Włodzimierz Samborski', Elżbieta Rostkowska² \\ ${ }^{1}$ Department of Rheumatology and Rehabilitation, Poznań University of Medical Sciences, Poland \\ 2 University of Computer Sciences and Skills Lodz, Poland
}

Kostiukow A, Kaluga E, Samborski W, Rostkowska E. The physiotherapeutic context of loss of dominant arm function due to occupational accidents. Ann Agric Environ Med. 2016; 23(4): 625-630. doi: 10.5604/12321966.1226857

\begin{abstract}
Introduction. The study examines the problem of dominant arm function loss in rural adult patients due to work-related accidents. The types of risks involved in farmyard work include falling from a height, manually moving loads, overturning/ accident whilst driving an agricultural tractor, noise and vibration, use of pesticides, and the risk of being cut or injured. The study focuses on adaptation of the non-dominant arm.

Objective. The main aim of the study was evaluation of visual-motor coordination on the basis of performance of the nondominant hand in patients after the loss of function of the dominant arm.

Materials and method. The research sample consisted of 52 patients with a permanent or temporary loss of function or severely limited function of the dominant arm. The subjects were patients with arm amputations due to various occupational injuries sustained while operating agricultural and construction machinery and forestry equipment, following traumas or complicated medical surgeries of the arm, or due to car accidents. The following tests were applied in the analysis: I) Dufour cross-shaped apparatus test for assessing visual motor-coordination; II) paper-and-pencil tests and the Relay Baton motor fitness test; III) anthropometric measurements; IV) Edinburgh Handedness Inventory; and V) a questionnaire survey.

Results. The results of the apparatus and motor tests indicate the same tendency: reaction to stimuli measured on the basis of performance of the non-dominant arm is longer in shorter and older patients.

Conclusions. Visual-motor coordination, as measured by the performance of the non-dominant arm, is significantly affected by the subject's body height and arm length.
\end{abstract}

\section{Key words}

occupational injury, visual motor coordination, upper extremity, amputation

\section{INTRODUCTION}

The development of modern civilization, mechanized agriculture and forestry, and means of transportation and industrialization, involves risks of traumas and subsequent loss of function of the extremities. The number of amputees and patients admitted to specialist clinics with medical problems disturbing the proper function of the arms is on the increase. It is still difficult to assess the precise number of amputees worldwide [1]. In 2005, there were 1.7 million amputees in the United States, and this number is estimated to double by 2050 [2]. Every year, 185,000 amputations are performed in the USA [3], and the cost of amputations carried out in 2009 amounted to more than 8 billion dollars [4]. Similar reports on amputations in Europe and Asia are also available $[5,6]$.

In the majority of the general population the dominant arm is the right arm, which reflects the dominance of the left cerebral hemisphere in performing motor tasks [7-10]. In the past, when knowledge on human neurobiology was limited, left-handed children were often trained to use their right arm for performing simple chores at home and at school.

Address for correspondence: Anna Kostiukow, Chair of Physiotherapy, Rheumatology and Rehabilitation, Poznań University of Medical Sciences, 28 czerwca 1956 135/147, 61-545 Poznań, Poland

E-mail: annakostiukow@wp.pl

Received: 28 March 2013; accepted: 03 November 2014
However, research shows that such practices failed to bring a switch in the children's handedness since, sooner or later, they resorted to using their dominant arm $[11,12]$. On the other hand, the situation of amputee patients after permanent loss of function of their (usually dominant) right arm can generate some research interest. There have been very few publications on this issue. A recent study proved that patients with permanent loss of function of the dominant arm (due to amputation) could attain the same level of performance of the non-dominant arm as the dominant arm (e.g. in drawing precision), if undergoing regular, intensive and long-term training [13]. This can be an important indication for the direction of rehabilitation of such patients.

Standard rehabilitation procedures for patients after the loss of function of the arm are aimed, first of all, at maintaining general fitness and maintaining or improving muscle strength of the damaged arm. Another significant aspect of rehabilitation is restoration of the range of motion of the entire shoulder girdle as close as possible to the physiological norm [14]. In amputee patients a parallel procedure is the appropriate use of prostheses [15]. The present research therefore deals with the situation in which a professionally and socially active person has lost the manipulative functions of the dominant hand in the course of daily and occupational activities. 


\section{OBJECTIVE}

The main aim of the study was evaluation of visual-motor coordination on the basis of performance of the non-dominant hand in patients after the loss of function of the dominant arm. The study intended to examine the relationship between patients' anthropometric parameters and the effectiveness of patients' training to perform motor tasks with the nondominant arm. The study also attempted to select the most optimal medical equipment for assessment of patients' visualmotor coordination in physiotherapeutic practice.

\section{MATERIALS AND METHOD}

The research sample consisted of 52 patients with permanent or temporary loss of function or severely limited function of the dominant arm. The male subjects were patients with arm amputations due to various causes, or following traumas or complicated medical surgeries of the arm, which had led to their temporary or permanent disability. They were mainly victims of work accidents that occurred during operating agricultural and construction machinery and forestry equipment. In the female patients under study, the main cause of their dominant arm function loss were car accident injuries.

One-third of the examined patients were women. The subjects' mean age was 45.5 years, with body mass between $50 \mathrm{~kg}-109 \mathrm{~kg}$ (mean $73.9 \mathrm{~kg}$ ), and mean body height of $171 \mathrm{~cm}$ $(153 \mathrm{~cm}-194 \mathrm{~cm})$. More than $60 \%$ of subjects had a vocational and secondary education ( $32.7 \%$ and $30.8 \%$, respectively). They included chainsaw operators, construction workers, glaziers and other physical workers following occupations involving upper limb-threatening conditions. Subjects with a higher education constituted about $25 \%$ of the sample, while the remaining subjects (13.4\%) had an elementary education.

Table 1. Mean values of selected characteristics of the study sample

\begin{tabular}{|c|c|c|c|c|c|}
\hline \multirow[t]{2}{*}{ Item } & \multirow{2}{*}{\multicolumn{3}{|c|}{ Characteristic }} & \multicolumn{2}{|c|}{$\begin{array}{c}\text { Mean value (from } \\
\text { among all examined } \\
\text { patients in the group) }\end{array}$} \\
\hline & & & & $\bar{x}$ & $\min -\max$ \\
\hline 1. & Gender & \multicolumn{2}{|c|}{$\begin{array}{l}\text { Male - } 36(69.2 \%) \\
\text { Female - } 16(30.8 \%)\end{array}$} & - & - \\
\hline 2. & \multicolumn{3}{|l|}{ Age [years] } & 45.5 & $20-84$ \\
\hline 3. & \multicolumn{3}{|c|}{ Body height $[\mathrm{cm}]$} & 171 & $153-184$ \\
\hline 4. & \multicolumn{3}{|c|}{ Body mass [kg] } & 73.9 & $50-109$ \\
\hline \multirow{3}{*}{5.} & \multicolumn{3}{|l|}{ Education } & \multirow{3}{*}{-} & \multirow{3}{*}{-} \\
\hline & \multicolumn{3}{|c|}{ Elementary $13.4 \%$. } & & \\
\hline & \multicolumn{3}{|c|}{ Secondary $30.8 \%$. Higher $23.1 \%$} & & \\
\hline 6. & \multicolumn{3}{|c|}{$\begin{array}{l}\text { Time after loss of function of the dominant arm } \\
\text { [days, years] }\end{array}$} & 2.8 years & 1 day-33 years \\
\hline \multirow{3}{*}{7.} & \multicolumn{3}{|c|}{ Patients' self-assessment of eyesight } & & \multirow{3}{*}{-} \\
\hline & $\begin{array}{l}\text { Very good } \\
28.8 \% \text {. }\end{array}$ & Good 19.3\%. & $\begin{array}{l}\text { Good }+ \\
\text { corrective lenses } \\
42.3 \% \text {. }\end{array}$ & - & \\
\hline & Poor $0 \%$ & Very poor $9.6 \%$ & - & & \\
\hline \multirow{2}{*}{8.} & \multicolumn{3}{|c|}{ Right-, left-handedness } & & \\
\hline & \multicolumn{3}{|c|}{ Right - 100\% I-0\% } & & \\
\hline 9. & \multicolumn{3}{|c|}{ Dominant arm length $[\mathrm{cm}]$} & 82 & $68-97$ \\
\hline
\end{tabular}

Table 2. Mean values of selected characteristics of patients aged 20-40 years

\begin{tabular}{|c|c|c|c|c|}
\hline \multirow[t]{2}{*}{ Item } & \multirow{2}{*}{\multicolumn{2}{|c|}{ Characteristic (age bracket $20-40$ years) }} & \multicolumn{2}{|c|}{$\begin{array}{l}\text { Mean value (from among } \\
\text { all examined patients in the } \\
\text { group) }\end{array}$} \\
\hline & & & $\bar{x}$ & $\min -\max$ \\
\hline 1. & Gender & $\begin{array}{l}\text { Male - } 16(84.2 \%) \\
\text { Female -3 }(15.8 \%)\end{array}$ & - & - \\
\hline 2. & Age [years] & & 29.7 & $20-40$ \\
\hline 3. & Body height $[\mathrm{cm}]$ & & 175.5 & $160-190$ \\
\hline 4. & Body mass $[\mathrm{kg}]$ & & 73.7 & $54-92$ \\
\hline \multirow{3}{*}{5.} & Education & & \multirow{3}{*}{ - } & \multirow{3}{*}{ - } \\
\hline & Elementary $10.6 \%$. & Vocational $36.8 \%$. & & \\
\hline & Secondary $26.3 \%$. & Higher 26.3\% & & \\
\hline
\end{tabular}

Table 3. Mean values of selected characteristics of patients aged 41-60 years

\begin{tabular}{|c|c|c|c|c|}
\hline \multirow[t]{2}{*}{ Item } & \multirow{2}{*}{\multicolumn{2}{|c|}{$\begin{array}{l}\text { Characteristic } \\
\text { (age bracket } 41-60 \text { years) }\end{array}$}} & \multicolumn{2}{|c|}{$\begin{array}{l}\text { Mean value (from among all } \\
\text { examined patients in the group) }\end{array}$} \\
\hline & & & $\bar{x}$ & $\min -\max$ \\
\hline 1. & Gender & $\begin{array}{l}69.2 \% \\
\text { ale } 30.8 \%\end{array}$ & - & - \\
\hline 2. & Age [years] & & 52.8 & $41-60$ \\
\hline 3. & Body height $[\mathrm{cm}]$ & & 169.9 & $153-192$ \\
\hline \multirow[t]{2}{*}{4.} & \multicolumn{2}{|l|}{ Body mass [kg] } & 76.1 & 55-109 \\
\hline & \multicolumn{2}{|l|}{ Education } & \multirow{3}{*}{-} & \multirow{3}{*}{-} \\
\hline \multirow[t]{2}{*}{5.} & Elementary $11.5 \%$ & Vocational $38.5 \%$ & & \\
\hline & Secondary $30.8 \%$ & Higher 19.2\% & & \\
\hline
\end{tabular}

Table 4. Mean values of selected characteristics of patients above 60 years of age

\begin{tabular}{|c|c|c|c|c|}
\hline \multirow[t]{2}{*}{ item } & \multirow{2}{*}{\multicolumn{2}{|c|}{$\begin{array}{l}\text { Characteristic (patients above } 60 \text { years } \\
\text { of age) }\end{array}$}} & \multicolumn{2}{|c|}{$\begin{array}{l}\text { Mean value (from among all } \\
\text { examined patients in the group) }\end{array}$} \\
\hline & & & $\bar{x}$ & $\min -\max$ \\
\hline 1. & Gender & $\begin{array}{l}\text { Male } 28.6 \% \\
\text { Female } 71.4 \%\end{array}$ & - & - \\
\hline 2. & Age [years] & & 66.7 & $61-84$ \\
\hline 3. & Body height $[\mathrm{cm}]$ & & 163 & $160-175$ \\
\hline \multirow[t]{2}{*}{4.} & \multicolumn{2}{|l|}{ Body mass [kg] } & 64.9 & $58-78$ \\
\hline & Education & & \multirow{3}{*}{ - } & \multirow{3}{*}{-} \\
\hline \multirow[t]{2}{*}{5.} & Elementary $14.3 \%$. & Vocational 0. & & \\
\hline & Secondary $57.1 \%$. & Higher $28.6 \%$ & & \\
\hline
\end{tabular}

All subjects were right-handed; $42.3 \%$ declared their eyesight as good but requiring corrective lenses. The mean number of years of loss/reduction of function of the dominant arm in the patients was 2.8 years.

Assessment of the adaptation abilities in patients after the loss of function or with limited function of the dominant arm focused on the analysis of visual motor coordination. The adaptation ability was understood as an ability to adjust to new motor conditions. The studied parameter of visual-motor coordination consisted of movements of the non-dominant hand. The research methods included:

Apparatus tests for assessment of patients' coordination abilities. Patients' visual motor coordination was assessed using the Dufour Cross-Shaped Apparatus (Alfa-Electronics) (Fig. 1) 


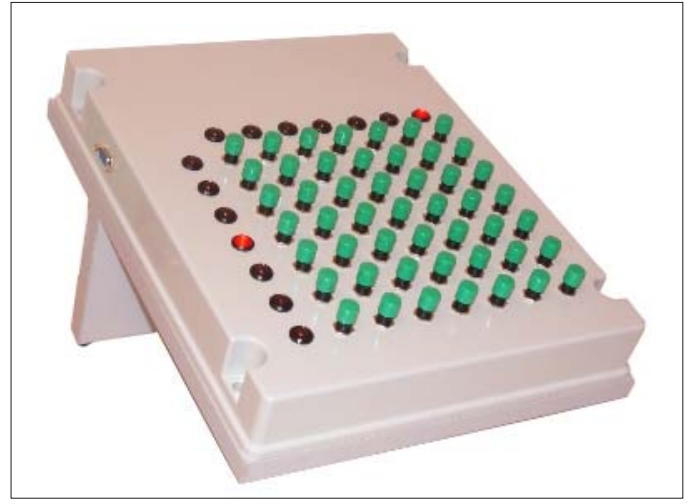

Figure 1. Dufour Cross-Shaped Apparatus.

The Dufour Cross-Shaped Apparatus is a compact device with a front panel with 49 buttons, surrounded by light-emitting stimuli. The stimuli are placed on either side and on the top of the panel. Subjects must press the button that corresponds to the two lamps from horizontal and vertical lines that are lit at the same time, testing their reaction to the light stimuli. [15-17]. Each patient carried out three trials at a random rate and at set rates of 30 and 40 light stimuli per minute. The obtained data on patients' individual, mean and total reaction times, number of errors, minimal and maximal reaction times, and stimuli which yielded errors were processed by a computer.

Functional tests for assessment of patients' coordination abilities. 'Paper-and-pencil tests' involving copying two geometric drawings with the non-dominant hand: a circle ('Circle Test') and an atypical square ('Atypical Square Test') on forms within two solid lines (Figs. 2 and 3). The drawing time was measured with a stopwatch, and the number of errors, i.e. deviations from the course within the lines, was counted for each subject.

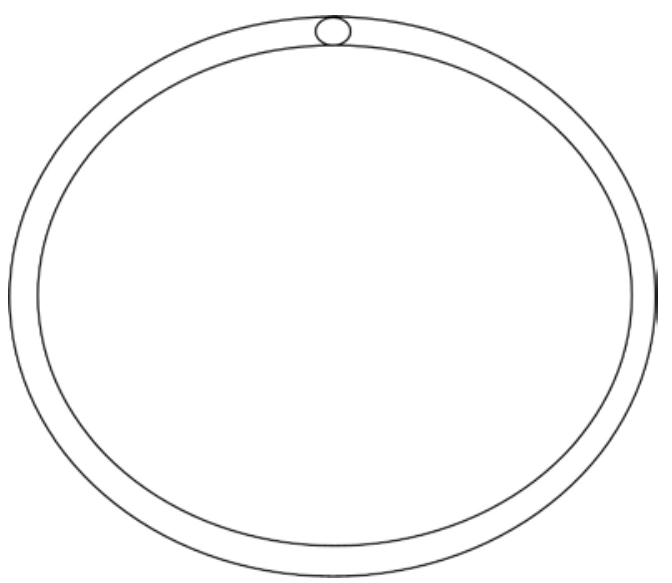

Figure 2. The form used in the Circle Test

The two functional tests were based on the Developmental Test of Visual-Motor Integration (an improved version of the Beery-Buktenica Developmental Test of Visual-Motor Integration) and the Visual-Motor Coordination Test assessing visual-motor perception [18-23].

The Relay Baton motor test consisting of moving back and forth a $40-\mathrm{cm}$ long 'relay baton' $(6 \mathrm{~cm}$ in diameter, $0.2 \mathrm{~kg}$ ) held in the hand of the extended non-dominant arm, as fast as possible without visual control (Fig. 4). The test was

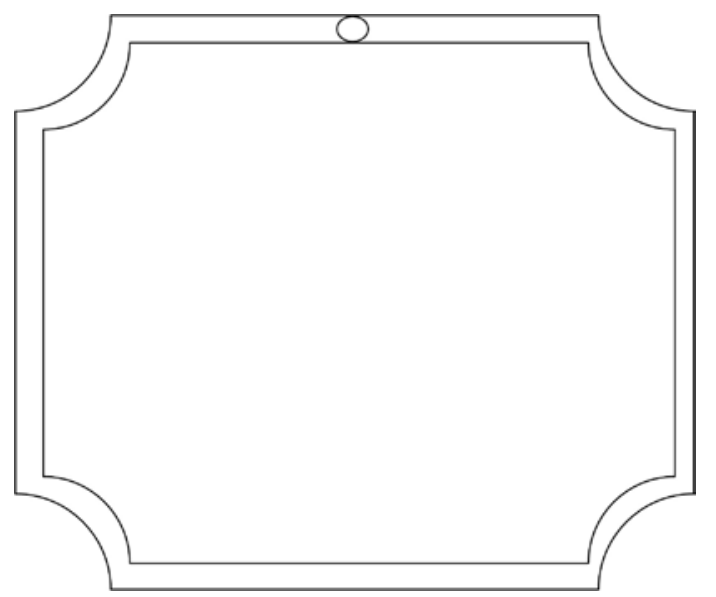

Figure 3. The form used in the Atypical Square Test

performed in a standing position. The time of test performance was measured with a stopwatch.

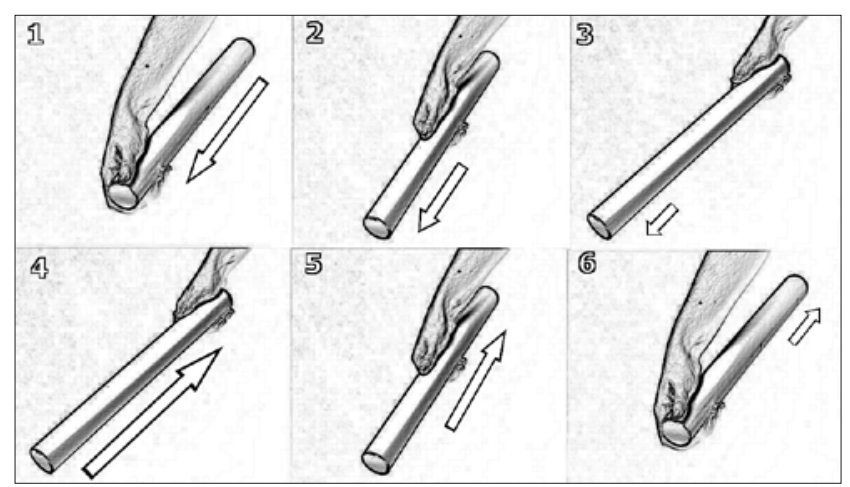

Figure 4. Execution of the Relay Baton test

The Relay Baton test is the authors' own motor test for assessment of coordination abilities. It consists of imitating a sequence of movements demonstrated by the examiner. The sequence used in the test indicates effectively the level of development of coordination abilities of the non-dominant hand.

Anthropometric measurements. The arm length was measured between the acromion /a/ and the dactylion iii / da iii/ (a-da III), whereas the body height was measured as the length between the vertex $/ \mathrm{v} /$ and the base on which the patient was standing / B/ (B-v). The measurements were made with the anthropometric tape [24].

Edinburgh Handedness Inventory (EHI). A questionnaire assessing the degree and type of lateralization, consisting of 10 items describing the use of the appropriate hand to perform activities of daily living [25-28].

Survey questionnaire. The authors' own survey questionnaire was used to obtain data on patients' health state.

The methodology and study protocol were approved by the Bioethical Committee of the Poznań University of Medical Sciences on 8 October 2009. 


\section{RESULTS}

The processing of results involved two statistical analyses. The first considered the subjects' age, and the other, selected anthropometric parameters. In the first analysis, the subjects were divided into three age groups:

- from 20 - 40 years of age (Group 1);

- from 41 - 60 years of age (Group 2);

- over 60 years of age (Group 3).

Since in statistical analysis three groups were compared at the same time, a non-parametric Kruskal-Wallis test was applied, which revealed statistically significant differences (Tab. 5).

Table 5. Comparison of results in three age groups together

\begin{tabular}{|c|c|c|c|c|}
\hline Test type & Test & Age groups & Result & $\begin{array}{l}\text { Significance } \\
\text { level } p\end{array}$ \\
\hline Motor test & Circle Test & Group 1 and Group 3 & $\begin{array}{l}H= \\
10.88\end{array}$ & $p \leq 0.01$ \\
\hline Motor test & Atypical Square Test & $\begin{array}{l}\text { Group } 1 \text { and Group 3; } \\
\text { Group } 2 \text { and Group } 3\end{array}$ & $\begin{array}{l}H= \\
10.86\end{array}$ & $p \leq 0.01$ \\
\hline Motor test & Relay Baton Test & $\begin{array}{l}\text { Group } 1 \text { and Group 3; } \\
\text { Group } 2 \text { and Group } 3\end{array}$ & $\begin{array}{l}H= \\
11.20 .\end{array}$ & $p \leq 0.01$ \\
\hline $\begin{array}{l}\text { Apparatus } \\
\text { test }\end{array}$ & $\begin{array}{l}\text { Random rate - mean } \\
\text { reaction time }\end{array}$ & $\begin{array}{l}\text { Group } 1 \text { and Group 2; } \\
\text { Group } 1 \text { and Group } 3\end{array}$ & $\begin{array}{l}H= \\
15.50 .\end{array}$ & $p \leq 0.001$ \\
\hline $\begin{array}{l}\text { Apparatus } \\
\text { test }\end{array}$ & $\begin{array}{l}\text { Random rate - total } \\
\text { reaction time }\end{array}$ & $\begin{array}{l}\text { Group } 1 \text { and Group 2; } \\
\text { Group } 1 \text { and Group } 3\end{array}$ & $\begin{array}{l}H= \\
18.19 .\end{array}$ & $p \leq 0.001$ \\
\hline $\begin{array}{l}\text { Apparatus } \\
\text { test }\end{array}$ & $\begin{array}{l}30 \text { stimuli/min.-mean } \\
\text { reaction time }\end{array}$ & $\begin{array}{l}\text { Group } 1 \text { and Group 2; } \\
\text { Group } 1 \text { and Group } 3\end{array}$ & $\begin{array}{l}H= \\
16.44\end{array}$ & $p \leq 0.001$ \\
\hline $\begin{array}{l}\text { Apparatus } \\
\text { test }\end{array}$ & $\begin{array}{l}30 \text { stimuli/min. - total } \\
\text { reaction time }\end{array}$ & Group 1 and Group 2 & $\begin{array}{l}\mathrm{H}= \\
8.01 .\end{array}$ & $p \leq 0.05$ \\
\hline $\begin{array}{l}\text { Apparatus } \\
\text { test }\end{array}$ & $\begin{array}{l}40 \text { stimuli/min. - total } \\
\text { reaction time }\end{array}$ & $\begin{array}{l}\text { Group } 1 \text { and Group 3; } \\
\text { Group } 2 \text { and Group } 3\end{array}$ & $\begin{array}{l}\mathrm{H}= \\
9.79 .\end{array}$ & $p \leq 0.01$ \\
\hline $\begin{array}{l}\text { Apparatus } \\
\text { test }\end{array}$ & $\begin{array}{l}40 \text { stimuli/min. - } \\
\text { minimal reaction time }\end{array}$ & Group 1 and Group 3 & $\begin{array}{l}\mathrm{H}= \\
9.26\end{array}$ & $p \leq 0.01$ \\
\hline
\end{tabular}

The results clearly show that younger subjects performed coordination exercises faster and with greater precision.

The subjects' anthropometric parameters in the second analysis included:

- body height (Parameter 1);

- non-dominant arm length (Parameter 2), between the acromion and the dactylion III.

Spearman's rank correlation coefficient used in the analysis revealed statistically significant correlations between the results of the following:

- Circle Test and Parameter 1 ( $\mathrm{p} \leq 0.01 ; \mathrm{R}=-0.381795)$;

- Atypical Square Test and Parameter $1(\mathrm{p} \leq 0.05 ; \mathrm{R}=-0.34)$;

- Relay Baton Test and Parameter 1 ( $\mathrm{p} \leq 0.001 ; \mathrm{R}=-0.53$ ).

- Apparatus Test - mean reaction time at a random rate and Parameter $1(\mathrm{p} \leq 0.05 ; \mathrm{R}=-0.31)$. These results indicate that shorter persons required more time to perform the test at a random rate;

- Apparatus test - total reaction time at a random rate and Parameter 1 ( $\mathrm{p} \leq 0.01 ; \mathrm{R}=-0.38$ );

- Apparatus test - mean reaction time at $30 / \mathrm{min}$ and Parameter $1(\mathrm{p} \leq 0.05 ; \mathrm{R}=-0.31)$;

- Apparatus test - minimal reaction time at $30 / \mathrm{min}$ and Parameter $1(\mathrm{p} \leq 0.05 ; \mathrm{R}=-0.34)$.
The relationships between subjects' body height and results of all three types of applied fitness and apparatus tests show that tall patients required less time to perform all the testing procedures.

- Circle Test and Parameter $2(\mathrm{p} \leq 0.01 ; \mathrm{R}=-0.41)$;

- Atypical Square Test and Parameter $2(\mathrm{p} \leq 0.01 ; \mathrm{R}=-0.35)$;

- Relay Baton test and Parameter 2 ( $\mathrm{p} \leq 0.001$; $\mathrm{R}=-0.53)$;

Comparison between the non-dominant arm length and results all three types of motor tests showed that patients with shorter arms required more time to perform specific testing procedures.

\section{DISCUSSION}

Research on adaptation in the case of disabilities caused by a temporary or irreversible loss of function of the dominant hand has been relatively recent. It is therefore rather difficult to compare the presented selection of methodology and analysis of results with those by other authors. So far, only Phillip and Frey have tackled the subject in their MRI study of brain function during movements of the non-dominant arm [14]. Although studies on visual motor coordination (a determinant of adaptation in the present study) in medical sciences have been conducted before $[29,30]$, they rarely concerned aspects of loss of function of the dominant hand $[31,32]$.

However, there have been a substantial number of research publications on work-related accidents in rural areas in different parts of the world [33-35]. Researchers have also established a number of classifications of accidents, including injuries of the upper extremity [36, 37]. The types of risks involved in farmyard work include falling from a height, manually moving loads, overturning/ accident whilst driving an agricultural tractor, noise and vibration, use of pesticides, and risk of being cut/injured [38]. Unfortunately, these accidents do not happen only to rural adults performing various works, but also to children. These problems must be addressed, proper school programmes should be provided and access to hazardous equipment should be restricted [39]. All these measures must lead to an awareness that occupational accidents and injuries in agriculture have serious psychological and economic consequences [40,41].

Interpretation of the results of the presented study was based on the calculation of statistically significant differences between the results of functional and motor tests (Circle, Atypical Square, Relay Baton tests) and apparatus tests (random rate, $30 / \mathrm{min}, 40 / \mathrm{min}$ ). The results confirm that the best visual motor coordination (understood as the body's adaptation) following the loss of function in the dominant hand can be expected in patients from the youngest age group (professionally active), and the worst in patients over 60 years of age. Statistically significant differences were found between these two groups, between patients' age and test results. Similar observations were made regarding a group of patients aged $41-60$ years of age. A lack of such differences can be justified by the wide age span in the oldest group of patients. In almost all cases, a characteristic tendency of decreasing visual motor coordination with age could be noted, i.e. longer times of reaction to specific stimuli and performance of motor tasks. 
The presented study also examines the possible influence of two anthropometric parameters (body height and length of the non-dominant arm that performed given motor tasks in able-bodies and disabled individuals) on visual motor coordination. The study results show that structural predispositions of the human body determine the proper quality of movements indicating the level of visual motor coordination in the examined study sample.

Analysis of both parameters in the study sample showed that tall persons with long arms performed new motor tasks faster with their hitherto less active non-dominant upper extremity (i.e. the adaptation process advanced more effectively). This is reflected by statistically significant correlations between test results and body height or arm length. It is important that body height appears to be a 'more significant' parameter in the examined group of individuals, as indicated by correlations with all fitness test results (Circle Test, Atypical Square Test and Relay Baton Test) and the majority of apparatus test results (random rate and 30/ min). The most significant indices in the presented study included total reaction time and minimal reaction time. As for relationships with the other parameter, i.e. non-dominant arm length, significant correlations were only revealed for the motor fitness tests.

Results of the analysis of the influence of anthropometric parameters on visual-motor coordination in patients after the loss/significant reduction of function of the dominant arm seem to indicate that shorter persons have generally lesser possibilities of adaptation. A similar study on a larger research sample could be a significant indication for modern neurorehabilitation in which recovery from injuries is related to changes in brain organization. The obtained results are 'averaged out'; therefore, there may be shorter persons with a high level of adaptive abilities as well as tall persons experiencing difficulties in performing motor tasks using their non-dominant arm.

The presented research was a valuable experience which yielded some unexpected conclusions. The measurement procedures were themselves exercises that can be effectively used in standard hospital treatment of these patients. Among the applied measurements the easiest to perform in each age group of patients were motor tests, being a sort of 'warm-up' before objective measurement tests using the cross-shaped apparatus. Some of the examined patients reported that the motor activity imposed by the examiners on their left hand (all of them were right-handed) was the first such an attempt in their life. Even the effort to sign their consent to participate in the experiment with their non-dominant hand was a valuable and satisfying rehabilitation exercise for them.

If the testing protocol described above is treated as a normal rehabilitation session, then the 'warm-up' consisting of motor tests was followed by the main exercises comprising visual motor coordination training using the cross-shaped apparatus. Although the apparatus is most commonly used in psychology and occupational medicine [15], it turned out to be a very good, portable and practical rehabilitation device. The apparatus tests constituted, indeed, an interesting experience for the patients.

The research subject of the study aroused great interest among the participating patients and medical staff. The study sample, especially the male subjects, constituted a very specific group. They were usually young or middle-aged males who were the bread-winners in families with many children, who could have worked for many years had it not been for the accident and resulting injuries. Despite many safety developments in agriculture or forestry, work accidents in these areas cannot be entirely eliminated. Therefore, efffective procedures and solutions in medical rehabilitation must be implemented.

\section{CONCLUSIONS}

The study provided good grounds for assessment of visual motor coordination in three age groups of patients with regard to two anthropometric parameters. The results show obviously that not only the patient's age, but also body height and arm length are crucial for determining the level of visual motor coordination, as manifested by movements of the nondominant hand; the level of adaptation was much higher in the youngest and tallest studied patients.

The study can be also beconsidered to be of a utilitarian character as the applied testing methods proved to be useful tools for the assessment of visual motor coordination in physiotherapeutic practice.

\section{REFERENCES}

1. Esquenazi A. Amputation rehabilitation and prosthetic restoration. From surgery to community reintegration. Disabil Rehabil. 2004 Jul 22-Aug 5; 26(14-15): 831-6.

2. Ziegler-Graham K, MacKenzie EJ, Ephraim PL, Travison TG, Brookmeyer R. Estimating the prevalence of limb loss in the United States-2005 to 2050. Arch Phys Med Rehabil. 2008; 89: 422-429.

3. Owings M, Kozak LJ, National Center for Health S. Ambulatory and Inpatient Procedures in the United States, 1996. Hyattsville, Md.: U.S. Dept. of Health and Human Services, Centers for Disease Control and Prevention, National Center for Health Statistics; 1998.

4. HCUP Nationwide Inpatient Sample (NIS). Healthcare Cost and Utilization Project (HCUP). Rockville, MD: Agency for Healthcare Research and Quality; 2009.

5. Pernot HFM, Winnubst GM, Cluitmans JJ, DeWitte LP. Amputees in Limburg: Incidence, morbidity and mortality, prosthetic supply, care utilization and functional level after one year. Prosthet Orthot Int. 2000; $24: 90-96$.

6. Ministry of Health Malaysia. Conference of 2nd National Health and Morbidity Survey: Diabetes Mellitus among adults age 30 years and above. Pub Health Instit. 1997; 9: 81 - 89.

7. Porter R, Lemon R. Corticospinal function and voluntary movement. Oxford: Clarendon; 1993.

8. Jacobs S, Danielmeier C, Frey SH. Human anterior intraparietal and ventral premotor cortices support representations of grasping with the hand or a novel tool. J Cogn Neurosci. 2010; 22: 2594-2608.

9. Shabbott BA, Sainburg RL. Differentiating between two models of motor lateralization. J Neurophysiol. 2008; 100: 565-575.

10. Geschwind DH, Miller BL, DeCarli C, Carmelli D. Heritability of lobar brain volumes in twins supports genetic models of cerebral laterality and handedness. Proc Natl Acad Sci USA. 2002; 99: 3176-3181.

11. Siebner HR, Limmer C, Peinemann A, Drzezga A, Bloem BR, Schwaiger M, Conrad B. Long-term consequences of switching handedness: a positron emission tomography study on handwriting in "converted" left-handers. J Neurosci. 2002; 22: 2816-2825.

12. Klöppel S, Vongerichten A, van Eimeren T, Frackowiak RS, Siebner HR. Can left-handedness be switched? Insights from an early switch of handwriting. J Neurosci. 2007; 27: 7847-7853.

13. Philip BA, Frey SH. Compensatory changes accompanying chronic forced use of the nondominant hand by unilateral amputees. J Neurosci. 2014 Mar 5; 34(10): 3622-31.

14. Kwolek A. Rehabilitacja medyczna. (Medical rehabilitation). URBAN\&PARTNER (Wrocław), 2003.

15. Waszkowska M, Dudek B. Aging and psychological assessment of motor vehicle driving capability. Med Pr. 2004; 55(6): 447-453. 
16. Płotek W, Cybulski M, Kluzik A, Grześkowiak M, Jelonek J, Switała W, Janicki J, Drobnik L. Psychomotor functions and interval timing in patients receiving intravenous anaesthesia for endoscopic procedures: the pilot study. ScientificWorldJournal. 2012; Vol. 2012.

17. Rotter T. Metodyka psychologicznych badań kierowców, Instytut Transportu Samochodowego (Warszawa), 2003.

18. Preda C. Test of Visual-Motor Integration: Construct validity in a comparison with the Beery-Buktenica Developmental Test of VisualMotor Integration. Percept Mot Skills. 1997; 84: 1439-1443.

19. Sortor JM, Kulp MT. Are the Results of the Beery-Buktenica Developmental Test of Visual-Motor Integration and Its Subtests Related to Achievement Test Scores? Opt Vis Sci. 2003; 80(11): 758-763.

20. Webb J, Abe K. Cross-Cultural Validity of the Developmental Test of Visual-Motor Integration. Percept Mot Skills. 1984; 58: 183-188.

21. Dankert HL, Davies PL, Gavin WJ. Occupational therapy effects on visual-motor skills in preschool children. Am J Occup Ther. 2003; 57(5): 542-9.

22. Campos TF. Silva SB, Fernandes MG, Araujo JF, Menezes AL. Diurnal Variation in Visual-Motor Coordination Test in Healthy Humans. Biol Rhyt Res. 2001; 32(2): 255-262.

23. Lewis GN, Byblow WD. Bimanual Coordination Dynamics in Poststroke Hemiparetics. J Mot Beh. 2004; 36(2): 174-188.

24. Drozdowski Z. Antropometria w wychowaniu fizycznym. Podręczniki Akademii Wychowania Fizycznego im. Eugeniusza Piaseckiego w Poznaniu, 1998; 24 (in Polish).

25. Oldfield RC. The assessment and analysis of handedness: The Edinburgh inventory. Neuropsychol. 1971; 9: 97-113.

26. Dane S, Yildirim S, Ozan E, Aydin N, Oral E, Ustaoglu N, Kirpinar I. Handedness, eyedness, and hand--eye crossed dominance in patients with schizophrenia: sex-related lateralisation abnormalities. Laterality. 2009; 14(1): 55-65.

27. Fasmer OB, Akiskal HS, Hugdahl K, Oedegaard KJ. Non-righthandedness is associated with migraine and soft bipolarity in patients with mood disorders. J Affect Disord. 2008; 108(3): 217-24.

28. Saltzman KM, Weems CF, Reiss AL, Carrión VG. Mixed lateral preference in posttraumatic stress disorder. J Nerv Ment Dis. 2006; 194(2): 142-4.

29. Hocherman S, Dimantb A, Schwartzc M. Visuo-motor coordination is normal in patients with major depression. Parkinsonism and Relat Disord. 2003; 9(6): 361-366.
30. Ramat S, Schmid R, Zambarbieri D. Eye-head coordination in darkness: Formulation and testing of a mathematical model. J Vestib Res. 2003; 13: 79-91.

31. Zambelis T, Tsivgoulis G, Karandreas N. Carpal tunnel syndrome: associations between risk factors and laterality. Eur Neurol. 2010; 63(1): 43-7.

32. Zuoza A, Skurvydas A, Mickeviciene D, Gutnik B, Zouzene D, Penchev $\mathrm{B}$, Pencheva S. Behavior of dominant and non dominant hands during ballistic protractive target-directed movements. Fiziol Cheloveka. 2009; 35(5): 62-70.

33. Crandall CS, Fullerton L, Olson L, Sklar DP, Zumwalt R. Farm- related injury mortality in New Mexico, 1980-91. Accid Anal Prev. 1997; 29: 257-61.

34. Marucci-Wellman H, Leamon TB, Willetts JL, Binh TT, Diep NB, Wegman DH, Kriebel D. Occupational injuries in a commune in rural Vietnam transitioning from agriculture to new industries. Am J Public Health. 2011; 101(5): 854-60.

35. Pickett W, Hagel L, Dosman JA. Saskatchewan Farm Injury Study Team. Safety features on agricultural machines and farm structures in Saskatchewan. J Agromedicine. 2012; 17(4): 421-4.

36. Ozyürekoğlu T, Napolitano M, Kleinert JM. Hay baler injuries to the upper extremity. J Trauma 2007; 63: 62-9.

37. Brower MA, Earle-Richardson GB, May JJ, Jenkins PL. Occupational injury and treatment patterns of migrant and seasonal farmworkers. J Agromedicine. 2009; 14(2): 172-8.

38. Antonucci A, Siciliano E, Ladiana D, Boscolo P, Di Sivo M. Perception of occupational risk by rural workers in an area of central Italy. J Biol Regul Homeost Agents. 2012; 26(3): 439-45.

39. Işık D, Ceylan MF, Tekin H, Karadaş S, Güner S, Canbaz Y. Upper extremity injuries due to threshing machine. Ulus Travma Acil Cerrahi Derg. 2012; 18(1): 55-60.

40. Copuroglu C, Heybeli N, Ozcan M, Yilmaz B, Ciftdemir M, Copuroglu E. Major Extremity Injuries Associated with Farmyard Accidents. ScientificWorldJournal. 2012; 2012: 314038.

41. Zaloshnja E, Miller TR, Lawrence B. Incidence and Cost of Injury Among Youth in Agricultural Settings, United States, 2001-2006. Pediatrics. 2012; 129(4): 728-34. 